\title{
Influence of Aminophylline and Cyclic AMP on Glycogen Metabolism in Fetal Rat Lung in Organ Culture
}

\author{
WILLIAM M. MANISCALCO, CHRISTINE M. WILSON, AND IAN GROSS \\ The Division of Perinatal Medicine, Departments of Pediatrics, and Obstetrics and Gynecology, Yale University \\ School of Medicine, New Haven, Connecticut, USA
}

\section{Summary}

The glycogen content of fetal rat lung declines coincident with increased pulmonary phospholipid synthesis. Aminophylline, a methylxanthine cyclic adenosine $3^{\prime}, 5^{\prime}$ monophosphate (AMP) phosphodiesterase inhibitor, and cyclic AMP augment fetal lung phospholipid synthesis. Because lung glycogen breakdown may contribute to pulmonary phospholipid synthesis, the effects of aminophylline and cyclic AMP on glycogen metabolism were studied in explants of 19 day fetal rat lung in organ culture. Treatment with aminophylline or dibutyryl cyclic AMP for $24 \mathrm{hr}$, resulted in a $25 \%(P<0.025)$ and $75 \%(P<0.001)$ decrease, respectively, in the glycogen conent of the explants. Glycogen synthase I activity was reduced by $32 \%$ in aminophylline treated cultures $(P<0.025)$ and $25 \%$ in cyclic AMP treated cultures $(P$ $<0.025$ ). The percent of total synthase in the active form was significantly reduced in all treated cultures. Neither aminophylline nor cyclic AMP treatment resulted in significant changes in glycogen phosphorylase a or total phosphorylase activity.

\section{Speculation}

The enhancement of fetal pulmonary surfactant by cyclic AMP and aminophylline may be due, in part, to the effects of these agents on lung carbohydrate metabolism.

Pulmonary surfactant is the phospholipid rich material which lines the alveoli of the lungs, preventing collapse due to surface tension at the air-alveolar interface (30). As the fetal lung develops late in gestation, there is increased synthesis of pulmonary surfactant while the epithelial cell glycogen content decreases $(4,14,18$, 31 ). The role of glycogen in fetal lung maturation is not clear. The temporal relationship between glycogen depletion and the acceleration of surfactant synthesis suggests that glucose derived from lung glycogen breakdown may contribute to pulmonary phospholipid synthesis. It is known that glucose is actively incorporated into surfactant phospholipids in both adult and fetal lung slices $(7,9,19)$. Furthermore, corticosteroid administration to the fetus both augments fetal lung surfactant synthesis (22) and decreases glycogen content $(7,13)$.

Theophylline, a methylxanthine cyclic adenosine 3 ' 5 ' monophosphate phosphodiesterase inhibitor, increases intracellular cAMP content (21) and also stimulates fetal lung surfactant synthesis $(1,12)$. Aminophylline is the ethylene diamine salt of theophylline. It has been previously demonstrated that aminophylline and cyclic AMP augment choline incorporation into phosphatidylcholine in explants of fetal rat lung in organ culture (8). Theophylline and cyclic AMP have also been shown to stimulate glycogen breakdown in fetal liver $(25,26)$ and adult muscle and liver $(11,21)$. Because glucose derived from lung glycogen breakdown may contribute to fetal lung surfactant syn- thesis, the effects of aminophylline and cyclic AMP on glycogen metabolism in explants of fetal rat lung have been examined.

\section{MATERIALS AND METHODS}

\section{CULTURE CONDITIONS}

Lung explants were prepared as described previously (8). Timed 19-day pregnant Sprague-Dawley rats (term is 22 days) were killed by a blow to the head. The fetuses were removed under sterile conditions and the lungs were removed from the fetuses, pooled, and chopped into $1 \mathrm{~mm}^{3}$ blocks by a mechanical tissue chopper. Approximately 20 explants were placed on a sterile millipore filter supported on a stainless steel grid in a plastic tissue culture dish. Waymouth's MB $752 / 1$ medium $(5.5 \mathrm{ml})$ was added to each culture dish so as to just wet the filter. The undersurface of the explants were, thus, exposed to the medium and the upper surface to the environment. The explants were incubated for $24 \mathrm{hr}$ at $37^{\circ} \mathrm{C}$ in a humidified atmosphere of $95 \% \mathrm{O}_{2}$ and $5 \% \mathrm{CO}_{2}$. Experimental cultures were incubated in medium to which aminophylline, 0.1-5.0 mM, or dibutyryl cyclic AMP, $0.2 \mathrm{mM}$, had been added. This concentration of dibutyryl cyclic AMP was chosen because it resulted in maximal stimulation of choline incorporation into phosphatidylcholine in previous lung explant experiments (8). After $24 \mathrm{hr}$ in culture, the explants were rapidly frozen in test tubes in a dry ice and ethanol bath and stored at $-70^{\circ} \mathrm{C}$ until analyzed.

\section{GLYCOGEN AND PROTEIN ANALYSIS}

Glycogen concentration was determined by the enzymatic fluorometric method of Lowry and Passonneau (16) in which NADPH production is measured after the tissue sonicate is treated with glycogen phosphorylase, phosphoglucomutase, and glucose6-phosphate dehydrogenase (GGPD). Approximately 30 explants were sonicated in $0.2 \mathrm{ml}$ cold $\mathrm{H}_{2} \mathrm{O}$. An aliquot of the sonicate was combined with an equal volume of $0.04 \mathrm{~N} \mathrm{HCl}$ and heated to $100^{\circ} \mathrm{C}$ for $10 \mathrm{~min}$. The glycogen content of this sample was determined in medium which contained $50 \mathrm{mM}$ imidizole buffer (pH 6.9), $3.0 \mathrm{mM} \mathrm{KH} \mathrm{PO}_{4}, 30 \mathrm{mM} \mathrm{NaF}, 0.2 \mathrm{mM}$ EDTA, $0.5 \mathrm{mM}$ adenosine-5'-phosphate, $0.9 \mathrm{mM} \mathrm{MgCl}_{2}, 0.5 \mathrm{mM}$ dithiothreitol, $0.02 \%$ bovine serum albumin, 60 uM NADP, 0.5 uM glucose-1, 6diphosphate, $0.09 \mathrm{U} / \mathrm{ml} \mathrm{G6PD}, 0.45 \mathrm{U} / \mathrm{ml}$ phosphoglucomutase, and $0.25 \mathrm{U} / \mathrm{ml}$ rabbit muscle glycogen phosphorylase a in a final volume of $2.2 \mathrm{ml}$. The reaction was initiated by the addition of $0.05 \mathrm{ml}$ of diluted tissue sonicate. The amount of NADPH generated was determined in a Perkin-Elmer fluorimeter (PerkinElmer, Norwalk, CT) when the reaction was complete, generally after $20-25 \mathrm{~min}$ at $20^{\circ} \mathrm{C}$. Sample values were compared to a standard curve derived from rabbit muscle glycogen.

Protein concentration was determined by the method of Lowry et al. (17) using bovine serum albumin as the standard. 


\section{ENZYME ANALYSIS}

Glycogen synthase (EC 2.4.1.11) activity of the explants was assayed by measuring the rate of incorporation of UDP[U- $\left.{ }^{14} \mathrm{C}\right]$ glucose into glycogen as described by Eisen et al. (6) after optimal $\mathrm{pH}$ and substrate concentrations were established. The explants were sonicated in buffer containing $20 \mathrm{mM}$ glycylglycine, $\mathrm{pH} 7.5$, $100 \mathrm{mM} \mathrm{NaF}, 3.0 \mathrm{mM}$ dithiothreitol, and $5.0 \mathrm{mM}$ EDTA. The final assay medium for glycogen synthase I contained $10 \mathrm{mM}$ UDP[U $-{ }^{14} \mathrm{C}$ glucose $(8.0 \mathrm{Ci} / \mathrm{mole}), 5 \mathrm{mg} / \mathrm{ml}$ glycogen, and 100 $\mathrm{mM}$ Tris- $\mathrm{HCl}, \mathrm{pH} 7.2$, in a final volume of $50 \mu \mathrm{l}$. The reaction was initiated by the addition of the sonicate, which contained approximately $0.2 \mathrm{mg}$ protein. For determination of total glycogen synthase $(I+D)$ activity, the final assay medium also contained $10 \mathrm{mM}$ glucose-6-phosphate, and the specific activity of the UDP[U $-{ }^{18} \mathrm{C}$ glucose was $2.0 \mathrm{Ci} / \mathrm{mole}$. After incubation for $10 \mathrm{~min}$ at $30^{\circ} \mathrm{C}$, aliquots of the reaction mixture were spotted on filter paper discs (Whatman \#31) for isolation of glycogen by the method of Thomas et al. (29). The filter paper discs were washed four times in $66 \%$ ethanol, rinsed in acetone, and allowed to dry. Radioactivity of the glycogen precipitate was determined in $10 \mathrm{ml}$ of Econofluor (New England Nuclear, Boston, MA) in a scintillation spectrometer. The reaction was linear with protein concentration up to at least $0.5 \mathrm{mg}$ per assay and with time for at least 30 min. Activity of glycogen synthase D was calculated as the difference between glycogen synthase I and total glycogen synthase (I + D) activities.

Glycogen phosphorylase (EC 2.4.1.1) activity of the explants was assayed by measuring the rate of generation of NADPH in an assay mixture which contained an excess of glycogen, phosphoglucomutase, and G6PD, by a modification of the method of Schwartz (25). Approximately 30 explants were sonicated in 0.20 $\mathrm{ml}$ of ice cold $75 \mathrm{mM} \mathrm{NaF}, 5.0 \mathrm{mM}$ EDTA, pH 6.7. Activity of

Table 1. The influence of aminophylline and dibutyryl cyclic AMP on the glycogen content of fetal rat lung in organ culture ${ }^{1}$

\begin{tabular}{|c|c|c|c|}
\hline Experiment & $\begin{array}{c}\text { Glycogen } \\
\text { content } \\
(\mu \mathrm{g} / \mathrm{mg} \\
\text { protein) }\end{array}$ & $\frac{\text { Treated }}{\text { Control }}$ & $P$ \\
\hline \multicolumn{4}{|l|}{ Aminophylline } \\
\hline 0 & $165.8 \pm 7.7$ & & \\
\hline $0.1 \mathrm{mM}$ & $169.7 \pm 15.9$ & $1.01 \pm 0.08$ & ns \\
\hline $0.5 \mathrm{mM}$ & $156.0 \pm 33.1$ & $0.99 \pm 0.25$ & ns \\
\hline $1.0 \mathrm{mM}$ & $126.0 \pm 9.4$ & $0.76 \pm 0.04$ & $<0.025$ \\
\hline $5.0 \mathrm{mM}$ & $251.0 \pm 22.9$ & $1.50 \pm 0.14$ & $<0.010$ \\
\hline \multicolumn{4}{|c|}{ Dibutyryl cyclic AMP: } \\
\hline 0 & $173.1 \pm 7.0$ & & \\
\hline $0.2 \mathrm{mM}$ & $43.9 \pm 2.6$ & $0.25 \pm 0.01$ & $<0.001$ \\
\hline Fresh 19-day lung: & $236 \pm 11.9$ & & \\
\hline
\end{tabular}

\footnotetext{
'Explants from 19 day fetal lungs were incubated for $24 \mathrm{hr}$ as described in the text. The values represent the mean \pm SE of $3-4$ experiments. Data from aminophylline and dibutyryl cyclic AMP treated explants were compared to those from untreated explants by $t$ test for independent variables ( $\mathrm{ns}=$ not statistically significant).
}

glycogen phosphorylase a was determined in medium containing $50 \mathrm{mM}$ imidazole buffer, $\mathrm{pH} 6.9,3.0 \mathrm{mM} \mathrm{KH}_{2} \mathrm{PO}_{4}, 30 \mathrm{mM} \mathrm{NaF}$, $0.2 \mathrm{mM}$ EDTA, $0.7 \mathrm{mg} / \mathrm{ml}$ glycogen, $0.5 \mathrm{uM}$ glucose-1, 6-diphosphate, $0.9 \mathrm{mM} \mathrm{MgCl}_{2}, 60 \mathrm{uM}$ NADP, $0.09 \mathrm{U} / \mathrm{ml} \mathrm{G6PD} 0.45 \mathrm{U} /$ $\mathrm{ml}$ phosphoglucomutase, $0.4 \mathrm{mM}$ caffeine, and tissue sonicate containing approximately 100 ug protein in a final volume of 2.2 $\mathrm{ml}$. The reaction was initiated by the addition of the tissue sonicate, and the rate of generation of NADPH was measured fluorometrically at $20^{\circ} \mathrm{C}$. Total glycogen phosphorylase $(\mathrm{a}+\mathrm{b})$ activity was assayed in medium without caffeine, but containing $1.5 \mathrm{mM}$ adenosine-5'-phosphate. The reactions were linear with protein concentration up to at least $180 \mathrm{ug}$ per assay and with time for at least $30 \mathrm{~min}$. Saturating amounts of all substrates were used.

\section{GLUCOSE OXIDATION}

After the $24 \mathrm{hr}$ culture period the rate of oxidation of $\left[\mathrm{U}-{ }^{14} \mathrm{C}\right]$ glucose to ${ }^{14} \mathrm{CO}_{2}$ was measured in the experimental and control explants. The culture medium was aspirated and replaced by Krebs-Ringers-phosphate solution ( $\mathrm{pH} 7.4$ ) containing $10 \mathrm{mM}$ [U${ }^{14} \mathrm{C}$ ]glucose (specific activity $0.075 \mathrm{Ci} / \mathrm{mole}$ ). The culture flask was placed in a sealed glass dish with side arm and a plastic well. The dish was flushed with $100 \% \mathrm{O}_{2}$ for 1 min and the side arm sealed. After a $2 \frac{1}{4} \mathrm{hr}$ incubation at $37^{\circ} \mathrm{C}, 0.3 \mathrm{ml}$ hyamine hydroxide was injected into the plastic well and the incubation continued for another $3 / 4 \mathrm{hr} .{ }^{14} \mathrm{CO}_{2}$ dissolved in the medium was released by acidification. The radioactivity of the hyamine hydroxide was determined in Econofluor.

All biochemicals were purchased from Sigma, St. Louis, MO and all radiochemicals were obtained from New England Nuclear, Boston, MA.

\section{RESULTS}

As is shown in Table 1, there was a significant decrease in the glycogen content of the explants cultured in the presence of 1.0 $\mathrm{mM}$ aminophylline as compared to controls. There was also a $75 \%$ decrease in the glycogen content of explants cultured in $0.2 \mathrm{mM}$ dibutyryl cyclic AMP. At high doses of aminophylline $(5.0 \mathrm{mM})$, the glycogen content was, however, greater than in the control cultures, but not different from fresh uncultured 19-day fetal lung. In organ culture, nutrients and pharmacologic agents reach the cells of the explant by diffusing through a block of tissue, which in this study, was $1 \mathrm{~mm}$ thick. It has been a common finding (8, 24) that relatively high concentrations of these substances are required for organ culture experiments and, for this reason, it is probably not appropriate to relate the drug levels used in this study to those that are used therapeutically.

Activity of glycogen synthase $I$, the active form of the enzyme, was significantly less in the explants cultured with $1.0 \mathrm{mM}$ aminophylline (Table 2). The percent of total glycogen synthase activity which was in the I form was also significantly less in the treated cultures. The activities of glycogen synthase $D$ and total glycogen synthase $(I+D)$ however, were unchanged. Essentially the same results were obtained when the explants were cultured in the presence of $0.2 \mathrm{mM}$ dibutyryl cyclic AMP (Table 3 ).

Table 2. The influence of $1.0 \mathrm{mM}$ aminophylline on glycogen synthase activity ${ }^{1}$

\begin{tabular}{|c|c|c|c|c|c|}
\hline & & & & Aminophylline & \\
\hline Enzyme $^{2}$ & $(n)$ & Control & Aminophylline & Control & $P$ \\
\hline Synthase I & (5) & $323 \pm 26$ & $218 \pm 28$ & $0.67 \pm 0.05$ & $<0.025$ \\
\hline Synthase $D^{3}$ & (5) & $2831 \pm 219$ & $2905 \pm 268$ & $1.02 \pm 0.05$ & ns \\
\hline Total Synthase & (5) & $3154 \pm 214$ & $3128 \pm 288$ & $0.99 \pm 0.05$ & ns \\
\hline I: total $(\%)$ & (5) & $10.5 \pm 1.1$ & $7.0 \pm 0.6$ & $0.68 \pm 0.05$ & $<0.025$ \\
\hline
\end{tabular}

' Culture conditions and statistical analysis were as described in Table 1.

${ }^{2}$ Enzyme activity is expressed as pmole $/ \mathrm{min} / \mathrm{mg}$ protein.

${ }^{3}$ Synthase D activity was calculated as the difference between total synthase and synthase I activity. 
The activities of glycogen phosphorylase a, the active form of the enzyme, total glycogen phosphorylase and the percentage of total activity in the active form were not affected by exposure to $1.0 \mathrm{mM}$ aminophylline (Table 4). (Glycogen phosphorylase b activity was decreased by $24 \%$ in these explants.) Similar results were obtained when the explants were exposed to $0.2 \mathrm{mM}$ cyclic AMP (Table 5).

The glycogen content of the control explants after $24 \mathrm{hr}$ of culture was lower than the glycogen content of fresh uncultured 19 day lung (Table 1). This decrease in glycogen content was associated with a significant increase in the activities of glycogen phosphorylase a and total glycogen phosphorylase in the explants, while the activity of glycogen synthase I was unchanged. In order to investigate the observation that explants cultured in $5.0 \mathrm{mM}$ aminophylline had a glycogen content similar to that of fresh 19day lung, the activities of glycogen synthase and phosphorylase were examined after exposure to this dose of the drug. The explants had decreased activity of glycogen synthase I (174 pmole/ $\mathrm{min} / \mathrm{mg}$ protein) while total glycogen synthase activity (3139 $\mathrm{pmole} / \mathrm{min} / \mathrm{mg}$ protein) was not changed. There was also, however, decreased activity of both glycogen phosphorylase a and total glycogen phosphorylase. $(2.08 \mathrm{nmole} / \mathrm{min} / \mathrm{mg}$ protein and $3.79 \mathrm{nmole} / \mathrm{min} / \mathrm{mg}$ protein, respectively.) The fraction of total phosphorylase in the active form in these explants was less than in control cultures $(55 \%)$. Thus, the relative increase in glycogen content observed after exposure to this presumably toxic dose was probably due to the inhibition of glycogen phosphorylase activity.

Production of ${ }^{14} \mathrm{CO}_{2}$ from [U-' ${ }^{4}$ C]glucose was measured to compare the overall viability of the aminophylline treated and control explants. As is shown in Table 6, exposure to $1.0 \mathrm{mM}$ aminophylline resulted in twice the rate of $\mathrm{CO}_{2}$ production from glucose.
Theophylline itself directly affects in vitro assays of glycogen phosphorylase (28) and glycogen synthase (5), probably by direct effects on the enzyme. To rule out the possibility that the changes in enzyme activities were due, in part, to direct in vitro effects of aminophylline which may have been transferred with the tissue into the assay medium, we performed a series of assays with varying amounts of added aminophylline. No direct effect of aminophylline on the activities of glycogen phosphorylase or synthase was noted.

\section{DISCUSSION}

It has been demonstrated that cyclic AMP and aminophylline, agents which enhance fetal lung surfactant production, also decrease the glycogen content of fetal rat lung explants. The decreased glycogen content correlated with decreased glycogen synthase I activity, but no significant stimulation of phosphorylase activity was found. In adult muscle and liver, glycogen breakdown is regulated by a complex series of reactions which result in activation of glycogen phosphorylase and inactivation of glycogen synthase $(10,27)$. This series of reactions may be initiated by activation of a cyclic AMP dependent protein kinase. In fetal liver explants, Sherline et al. (26) reported that acute treatment with cyclic AMP resulted in increased glycogen phosphorylase activity and decreased glycogen synthase activity, suggesting that regulation of glycogen metabolism in fetal and adult liver may be similar. Schwartz and Rall (25), however, found that whereas cyclic AMP treatment decreased the glycogen content of fetal rat liver explants, this effect was mediated only by decreased glycogen synthase I activity and not by increased phosphorylase activity. The authors' results with fetal lung explants are, thus, similar to those of Schwartz and Rall. The decreased glycogen content in

Table 3. The influence of $0.2 \mathrm{mM}$ dibutyryl cyclic AMP on glycogen synthase activity

\begin{tabular}{|c|c|c|c|c|c|}
\hline \multirow[b]{2}{*}{ Enzyme $^{2}$} & \multirow[b]{2}{*}{$(n)$} & \multirow[b]{2}{*}{ Control } & \multirow[b]{2}{*}{ Cyclic AMP } & \multirow{2}{*}{$\begin{array}{c}\text { Cyclic AMP } \\
\text { Control }\end{array}$} & \multirow[b]{2}{*}{$P$} \\
\hline & & & & & \\
\hline Synthase I & (4) & $295 \pm 24$ & $217 \pm 7$ & $0.75 \pm 0.05$ & $<0.025$ \\
\hline Synthase $\mathrm{D}^{3}$ & (4) & $2474 \pm 212$ & $2851 \pm 177$ & $1.16 \pm 0.06$ & ns \\
\hline Total synthase & (4) & $2770 \pm 204$ & $3068 \pm 178$ & $1.11 \pm 0.04$ & ns \\
\hline I: Total $(\%)$ & (4) & $10.9 \pm 1.4$ & $7.2 \pm 0.4$ & $0.68 \pm 0.08$ & $<0.05$ \\
\hline
\end{tabular}

${ }^{1}$ Culture conditions and statistical analysis were as described in Table 1.

${ }^{2}$ Enzyme activity is expressed as pmole $/ \mathrm{min} / \mathrm{mg}$ protein.

${ }^{3}$ Synthase $D$ activity was calculated as the difference between total synthase and synthase I activity.

Table 4. The influence of aminophylline on glycogen phosphorylase activity

\begin{tabular}{llcccc}
\hline & & & \multicolumn{2}{c}{ Aminophylline } \\
\cline { 4 - 5 } \multicolumn{1}{c}{ Enzyme $^{2}$} & $(n)$ & Control & Aminophylline & \multicolumn{2}{c}{ Control } \\
\hline Phosphorylase a & $(5)$ & $3.81 \pm 0.03$ & $3.89 \pm 0.19$ & $1.04 \pm 0.07$ & $\mathrm{~ns}$ \\
Phosphorylase $\mathrm{b}^{3}$ & $(5)$ & $1.97 \pm 0.12$ & $1.45 \pm 0.12$ & $0.76 \pm 0.10$ & $<0.025$ \\
Total Phosphorylase & $(5)$ & $5.79 \pm 0.11$ & $5.34 \pm 0.23$ & $0.92 \pm 0.03$ & $\mathrm{~ns}$ \\
a: Total (\%) & $(5)$ & $65.6 \pm 3.0$ & $72.8 \pm 1.9$ & $1.12 \pm 0.06$ & $\mathrm{~ns}$ \\
\hline
\end{tabular}

' Culture conditions and statistical analysis were as described in Table 1 .

${ }^{2}$ Enzyme activity is expressed as nmoles NADPH generated $/ \mathrm{min} / \mathrm{mg}$ protein.

${ }^{3}$ Phosphorylase $b$ activity was calculated as the difference between total pinosphorylase and phosphorylase a activity.

Table 5. The influence of $0.2 \mathrm{mM}$ dibutyryl cyclic AMP on glycogen phosphorylase activity

\begin{tabular}{|c|c|c|c|c|c|}
\hline \multirow[b]{2}{*}{ Enzyme $^{2}$} & \multirow[b]{2}{*}{$(n)$} & \multirow[b]{2}{*}{ Control } & \multirow{2}{*}{$\begin{array}{c}\text { Dibutyryl } \\
\text { cyclic AMP }\end{array}$} & \multicolumn{2}{|l|}{ Cyclic AMP } \\
\hline & & & & Control & $\boldsymbol{P}$ \\
\hline Phosphorylase a & (4) & $3.38 \pm 0.10$ & $3.84 \pm 0.24$ & $1.14 \pm 0.10$ & ns \\
\hline Phosphorylase $b$ & (4) & $1.96 \pm 0.03$ & $1.81 \pm 0.12$ & $0.93 \pm 0.07$ & ns \\
\hline Total phosphorylase & (4) & $5.34 \pm 0.08$ & $5.65 \pm 0.13$ & $1.06 \pm 0.04$ & ns \\
\hline a: Total $(\%)$ & (4) & $63.1 \pm 1.11$ & $67.9 \pm 2.7$ & $1.08 \pm 0.06$ & ns \\
\hline
\end{tabular}

1 Culture conditions and statistical analysis were as described in Table 1.

${ }^{2}$ Enzyme activity is expressed as nmoles $\mathrm{NADPH}$ generated $/ \mathrm{min} / \mathrm{mg}$ protein. 
Table 6. The influence of $1.0 \mathrm{mM}$ aminophylline on the rate of glucose oxidation to $\mathrm{CO}_{2}{ }^{1,2}$

\begin{tabular}{ccccc}
\hline & & \multicolumn{3}{c}{ Aminophylline } \\
$(n)$ & Control & Aminophylline & Control & P \\
\hline (3) & $9.8 \pm 0.1$ & $20.6 \pm 0.3$ & $2.10 \pm 0.01$ & $<0.001$ \\
\hline
\end{tabular}

' Culture conditions and statistical analysis were as described in Table 1 .

${ }^{2}$ Data is expressed as nmoles glucose oxidized/hour/mg protein.

these explants is probably the result of inhibition of glycogen synthase activity. Because glycogen phosphorylase activity was greater in control explants than in fresh uncultured lung, further activation with aminophylline or cyclic AMP may not be possible. Hess et al. (11) have also noted failure to increase phosphorylase a activity with theophylline in the rat diaphragm.

The function of glycogen in fetal lung is obscure, but its developmental pattern in late gestation lung $(4,18)$ suggests that it may contribute to pulmonary surfactant synthesis. Glucose derived from prenatal lung glycogenolysis may provide energy, substrates, or cofactors necessary for pulmonary phospholipid synthesis. Fetal lung readily incorporates glucose into phospholipids, especially phosphatidylcholine $(7,9)$. Furthermore, de novo fatty acid synthesis requires NADPH, and glucose metabolized through the hexose monophosphate pathway may be a source of this cofactor. Other indirect evidence which suggests that glycogen may contribute to fetal lung surfactant synthesis includes the observation that glucocorticoids both accelerate pulmonary surfactant synthesis and decrease glycogen content $(9,13,22)$ and the demonstration that there is increased lung glycogen and decreased pulmonary maturation in fetal rats decapitated in utero (2). These data, which show lung glycogen depletion by agents which augment surfactant synthesis, provide further indirect support of this hypothesis.

It is clear that theophylline itself has direct effects on in vitro assays for glycogen phosphorylase and synthase $(5,28)$. In this study, these effects were probably minimal because there was no difference in activity when these two enzymes were assayed with and without aminophylline in the reaction medium.

Cyclic AMP and theophylline have wide-ranging effects on pathways of carbohydrate metabolism other than that of glycogen. These include induction of fetal liver glucose-6-phosphatase activity (23), stimulation of hepatic phosphofructokinase (20), and pyruvate kinase (3) activity, and augmentation of glucose uptake by hamster embryo cells (15). The enhancement of fetal lung phospholipid synthesis by cyclic AMP could thus be mediated by a direct action on the enzymes of phospholipid synthesis or by its multiple effects on carbohydrate metabolism.

\section{REFERENCES AND NOTES}

1. Barrett, L. T. Sevanian, A., Lavin, N., and Kaplan, S. A.: Role of adenosine 3',5'-monophosphate in maturation of fetal lungs. Pediatr. Res., 10:621 (1976).

2. Blackburn, W. R.: Hormone influences in fetal lung development. In: C. A. Villee: Respiratory Distress Syndrome, p. 271 (Academic Press, New York. 1973).

3. Blair, J. B., Cimbla, M. A., Foster, J. L., and Morgan, R. A.: Hepatic pyruvate kinase: regulation by glucagon, cyclic adenosine $3^{\prime}: 5^{\prime}$ monophosphate, and insulin in the perfused rat liver. J. Biol. Chem.. 251: 3156 (1976).

4. Brandstrup. N., and Kretchmer, N.: The metabolism of glycogen in the lungs of the fetal rabbit. Dev. Biol., I1: 202 (1965).

5. DeWulf. H., and Hers, H. G.: The interconversion of liver glycogen synthetase $a$ and $b$ in vitro. Eur. J. Biochem., 6: 552 (1968).
6. Eisen, H. J., Goldfine. I. D.. and Glinsmann. W. H.: Regulation of hepatic glycogen synthesis during fetal development: roles of hydrocortisone, insulin and insulin receptors. Proc. Nat. Acad. Sci. USA, 70: 3454 (1973).

7. Gilden, C., Sevanian, A., Tierney, D. F., Kaplan, S. A., and Barrett. C. T.: Regulation of fetal lung phosphatidylcholine synthesis by cortisol: role of glycogen and glucose. Pediatr. Res., 11: 845 (1977).

8. Gross, I. and Rooney, S. A.: Aminophylline stimulates the incorporation of choline into phospholipid in explants of fetal rat lung in organ culture. Biochim. Biophys. Acta, 488: 263 (1977).

9. Hamosh. M., Schechter, Y., and Hamosh, P.: Metabolic activity of developing rabbit lung. Pediatr. Res., 12: 95 (1978).

10. Hers, H. G.: The control of glycogen metabolism in the liver. Ann. Rev. Biochem., 45: 167 (1976)

11. Hess, M. E., Hottenstein. D., Shanfeld, J., and Haugaard. N.: Metabolic effects of theophylline in cardiac and skeletal muscle. J. Pharm. Exp. Ther., 141: 274 (1963).

12. Karotkin. E. H., Kido, M., Cashore, W. J., Redding, R. A., Douglas, W. J., Stern L., and Oh, W.: Acceleration of fetal lung maturation by aminophylline in pregnant rabbits. Pediatr. Res., 10: 722 (1976).

13. Kikkawa. Y., Karbara, M., Motoyama, E. K., Orzalesi, M. M., and Gluck, L. Morphologic development of fetal rabbit lung and its acceleration with cortisol. Am. J. Path. 64: 423 (1971).

14. Kikkawa, Y., Motoyama. E. K., and Gluck. L.: Study of the lungs of fetal and newborn rabbits. Am. J. Path., 52: 177 (1968).

15. Kuroki, T. and Yamakawa. S.: The effects of dibutyryl cyclic adenosine $3^{\prime}: 5^{\prime}$ monophosphate and theophylline on 2-deoxy-D-glucose and 2-aminoisobutyric acid uptake by hamster embryo cells. Int. J. Cancer, 14: 32 (1974).

16. Lowry, O. H., and Passonneau, J. V.: In: A Flexible System of Enzyme Analysis (Academic Press, New York, 1972).

17. Lowry, O. H., Rosebrouger, N. J., Farr, A. L., and Randall, R. J.: Protein measurement with the folin phenol reagent. J. Biol. Chem., 193: 265 (1951)

18. Maniscalco, W. M., Wilson, C. M., Gross, I., Gobran, L., Rooney, S. A., and Warshaw, J. B.: Development of glycogen and phospholipid metabolism in fetal and newborn rat lung. Biochim. Biophys. Acta, 530: 333 (1978)

19. Moxley, M. A., and Longmore, W. J.: Effect of experimental diabetes and insulin on lipid metabolism in the isolated perfused rat lung. Biochim. Biophys. Acta. 488: 218 (1977).

20. Meldolesi, M. F.. Macchia, V.. and Varrone. S.: Phosphofructokinase (isozymes) activation by theophylline or by 3',5' cyclic AMP administration. Horm. Metab. Res., 9: 128 (1977).

21. Robison, G. A., Butcher, R. W., and Sutherland, E. W.: In: Cyclic AMP. p. 153 (Academic Press, New York. 1971).

22. Rooney, S. A., Gobran, L.. Gross, I.. Wai-Lee, T. S., Nardone, L. L., and Motoyama. E. K.: Studies on pulmonary surfactant: effects of cortisol admin istration to fetal rabbits on lung phospholipid content. composition, and biosynthesis. Biochim. Biophys. Acta, 450: 121 (1976).

23. Schwartz, A. L., Raiha, N. C. R., and Rall, T. W.: Effect of dibutyryl cyclic AMP on glucose-6-phosphatase activity in human fetal liver explants. Biochim. Biophys. Acta, 343: 500 (1974).

24. Schwartz A. L. Raiha, N. C. R., and Rall. T. W.: Hormonal regulation of glycogen metabolism in human fetal liver. I. Normal development and effects of dibutyryl cyclic AMP, glucagon, and insulin in liver explants. Diabetes, 24: 1101 (1975).

25. Schwartz, A. L. and Rall. T. W.: Hormonal regulation of glycogen metabolism in neonatal rat liver. Biochem. J., 134: 985 (1973).

26. Sherline, P., Eisen, H., and Glinsmann, W.: Acute hormonal regulation of cyclic AMP content and glycogen phosphorylase activity in fetal liver in organ culture. Endocrinology, 94: 935 (1974).

27. Soderling, T. R., and Park, C. R.: Recent advances in glycogen metabolism. Adv. Cyclic Nucl. Res., 4: 283 (1974).

28. Sutherland, E. W.: In: W. D. McElroy and B. Glass: Phosphorus Metabolism p 53 (The Johns Hopkins Press, Baltimore. (1951).

29. Thomas, J. A., Schendler, K. K., and Larner, J.: A rapid filter paper assay for UDP-glucose-glycogen glucosyltransferase, including an improved biosynthesis of UDP ${ }^{14} \mathrm{C}$-glucose. Anal. Biochem., 25: 486 (1969).

30. Tierney, D. F.: Lung metabolism and biochemistry. Ann. Rev. Physiol., 30: 209 (1974).

31. Williams, M. C., and Mason, R. J.: Development of the type Il cell line in fetal rat lung. Am. Rev. Resp. Dis., 115: 37 (1977).

32. This research was supported by United States Public Health Service grant HL 19752. Dr. Maniscalco was supported by United States Public Health Service Research Fellowship Award no. HD 05364.

33. Requests for reprints should be addressed to: Dr. Ian Gross, Department of Pediatrics, Yale University School of Medicine, 333 Cedar Street. New Haven. Connecticut 06510 (USA).

34. Received for publication June 13, 1978.

35. Accepted for publication November 15, 1978. 